\section{Kidney \\ Blood Pressure Research}

Original Paper

\title{
Energy and Oxygen Metabolism Disorder During Septic Acute Kidney Injury
}

\author{
Rong-li Yang ${ }^{\mathrm{a}}$ Xiao-ting Wang ${ }^{\mathrm{a}}$ Da-wei Liu ${ }^{\mathrm{a}}$ Si-bo Liub \\ ${ }^{a}$ Critical Care Medicine Department, Peking Union Medical College Hospital, Peking Union Medical \\ College and Chinese Academy of Medical Sciences, Beijing 100730; ${ }^{\text {CC }}$ ritical Care Medicine \\ Department, Affiliated Dalian Municipal Central Hospital of Dalian Medical University, Dalian, China
}

\section{Key Words}

Septic shock • Acute kidney injury • Apoptosis • Energy metabolism • Renal oxygen metabolism - Renal hemodynamics

\begin{abstract}
Background/Aims: Acute kidney injury (AKI) during septic shock, which is one of the most common clinical syndromes in the intensive care unit (ICU), has a high mortality rate and poor prognosis, partly because of a poor understanding of the pathogenesis of renal dysfunction during septic shock. Although ischemic injury of the kidney has been reported to result from adenosine triphosphate (ATP) depletion, increasing evidence has demonstrated that AKI occurs in the absence of renal hypoperfusion and even occurs during normal or increased renal blood flow (RBF); nevertheless, whether energy metabolism disorder is involved in septic AKI and whether it changes according to renal hemodynamics have not been established. Moreover, tubular cell apoptosis, which is closely related to ATP depletion, rather than necrosis, has been shown to be the major form of cell injury during AKI. Methods: We used canine endotoxin shock models to investigate the hemodynamics, renal energy metabolism, renal oxygen metabolism, and pathological changes during septic AKI and to explore the underlying mechanisms of septic AKI. Results: The present results revealed that the nicotinamide adenine dinucleotide $\left(\mathrm{NAD}^{+}\right)$pool and the ATP/adenosine diphosphate (ADP) ratio were significantly decreased during the early phase of septic AKI, which is accompanied by a decreased renal oxygen extraction ratio $\left(\mathrm{O}_{2} \mathrm{ER} \%\right)$ and decreased renal oxygen consumption $\left(\mathrm{VO}_{2}\right)$. Furthermore, significant apoptosis was observed following renal dysfunction. RBF and renal oxygen delivery were not significantly altered. Conclusion: These results suggest that imbalanced energy metabolism, rather than tubular cell apoptosis, may be the initiator of renal dysfunction during septic shock.
\end{abstract}

Copyright (C) 2014 S. Karger AG, Basel

Rong-li Yang and Xiao-ting Wang contributed equally to this work and thus share first authorship.

Da-wei Liu, MD

Critical Care Medicine Department, ICU, Peking Union Medical College Hospital

Dongcheng District, 1, Shuaifu Yuan, Wangfujing, Beiling City, 100370 (China)

Tel. 010-65296094, Fax 010-691523190, E-Mail dwliu@medmail.com.cn 


\section{Kidney Blood Pressure Research}

\section{Introduction}

Sepsis or septic shock is notably the most predominant cause of acute kidney injury (AKI) in critically ill patients $[1,2]$; however, the pathogenesis of renal dysfunction during septic shock has not been established. Currently, the hypotheses based on clinical and animal experiments are primarily focused on renal hemodynamics, inflammatory responses, sympathetic nerve activity, and renal tubular cell death [3, 4]. Whether energy and oxygen metabolism disorders are involved in the complicated start of renal injury and whether they are correlated with renal hemodynamics and tubular cell death have not been established.

It appears that hyperdynamic circulation occurs most frequently in septic shock patients during the early phase. In the majority of these patients, RBF either remains the same or is increased (3). Additionally, various views concerning changes in renal metabolism (including oxygen delivery, extraction, and consumption), tubular reabsorption, and glomerular filtration rate (GFR) $[2,5]$ tend to yield contradictory underlying mechanisms of septic AKI. A new concept that microcirculatory dysfunction, rather than hypoperfusion, is a major contributor to the pathogenesis of AKI [6, 7], which has not been supported by credible evidence, raises the question of what is the real cause of renal injury during septic shock.

Recently, apoptosis has been reported to be the major form of renal cell injury $[4,8$, 9]; however, we question whether the number of apoptotic cells observed in the kidney is large enough to be significant because we possess two kidneys with compensatory ability. Furthermore, most injured tubular cells progress toward apoptosis rather than necrosis, thus leading us to believe that whatever causes renal cell apoptosis may be responsible for early renal dysfunction. Several publications have reported that mitochondrial damage and energy metabolism disorder are characteristics of apoptosis, and the cellular ATP level may represent a threshold dividing apoptosis from necrocytosis [10-12]. Moreover, the rapid recovery of the ATP level can inhibit cell apoptosis and minimize organ dysfunction [13]. Based on this evidence, we can conclude that energy metabolism plays a significant role in cell apoptosis. If the dysfunction of renal microcirculation is critical in the pathogenesis of septic AKI, then energy and oxygen metabolism disorders should be observed in the early phase of renal dysfunction. Guided by this evidence, our study assessed the dynamic changes of RBF, renal function, renal oxygen metabolism, renal energy metabolism, and cell death patterns to analyze what type of role energy metabolism and cell apoptosis play in septic AKI pathogenesis and whether they are accompanied by oxygen metabolism disorder.

\section{Materials and Methods}

\section{Animal preparation}

All experimental and surgical procedures were approved by the Institute of Animal Care and Use Committee, and all efforts were made to minimize the animals' suffering and the number of canines involved in the experiment. Except for animals that died before monitoring was performed, 24 mongrel canines (19.2 $\pm 2.1 \mathrm{~kg}$ ) were raised in a quiet and warm environment according to the Principles of Laboratory Animal Care, and they had no access to food but free access to water for $12 \mathrm{~h}$ before the experiment. The canines were randomly divided into control $(n=6), 2-h(n=6), 4-h(n=6)$, and 6-h $(n=6)$ groups, before which the baseline parameters, including gender, weight, and height, were analyzed to avoid nonspecific differences.

Chemicals and reagents

Lipopolysaccharide (LPS) (Escherichia coli, 055:B5), ATP, ADP, NAD ${ }^{+}$, and phosphocreatine (PCr) were purchased from Sigma-Aldrich Corp. Pentobarbital sodium was obtained from Merck Corp. The In Situ Cell Death Detection Kit was purchased from Roche Applied Science. 


\section{Kidney Blood Pressure Research}

\section{Model of LPS-induced septic AKI}

The canines were anesthetized by an intraperitoneal injection of pentobarbital $(30 \mathrm{mg} / \mathrm{kg})$ and placed in the supine position. Tracheal intubation was performed, and the endotracheal tube was connected to a Servo Ventilator $900 \mathrm{C}$ breathing machine (VT=8-10 ml $/ \mathrm{kg}, \mathrm{f}=15-20 / \mathrm{min}, \mathrm{PEEP}=0 \mathrm{mmHg}, \mathrm{FiO}_{2}=30-50 \%$, $\mathrm{PetCO}_{2}=25-35 \mathrm{mmHg}$ ) to maintain the $\mathrm{PaO}_{2}$ at approximately $100 \mathrm{mmHg}$. A dual-lumen catheter (Edwards) was inserted into the right femoral vein, which allowed for continuous pumping of liquid, anesthetics (pentobarbital, $4 \mathrm{mg} / \mathrm{kg} / \mathrm{h}$ ), and neuromuscular blocking agents (NMBAs, vecuronium at an initial dose of $0.1 \mathrm{mg} / \mathrm{kg}$, followed by $0.05 \mathrm{mg} / \mathrm{kg} / \mathrm{h}$ ). A PICCO arterial duct and Swan-Ganz (Edwards) catheter were inserted into the right femoral artery and right external jugular vein, respectively, for continuous recording of systemic hemodynamic values and blood sampling. The RBF was measured through the left renal artery using a Doppler flow meter (TS410, Transonic Systems, Ithaca, NY, USA). Controlled infusion of LPS (2 mg/ $\mathrm{kg}$, at $1 \mathrm{mg} / \mathrm{kg} \cdot \mathrm{min}$ ) was conducted through a pulmonary artery catheter $30 \mathrm{~min}$ postoperatively when the vital signs were stable [14]. Normal saline $(4.3 \pm 0.6 \mathrm{ml} / \mathrm{kg} \cdot \mathrm{h})$ was instilled to maintain the central nervous pressure (CVP) and pulmonary artery wedge pressure (PAWP) at baseline levels to prevent hypodynamic circulation; it was important to simulate the most common clinical scenario in patients. Samples of the cortex, corticomedullary zone, and medulla were separately harvested $0,2,4$, and $6 \mathrm{~h}$ after LPS infusion in the control, 2-h, 4-h, and 6-h groups.

\section{Hemodynamic monitoring}

Systemic hemodynamic indexes, such as mean arterial pressure (MAP), systolic arterial pressure (SAP), and stroke volume (SV), were continuously recorded using PICCO, whereas PAWP and PVR were monitored using a Swan-Ganz (Edwards) catheter. Blood samples from the kidney were collected from the Swan-Ganz catheter (the blood gas values in the femoral artery blood and renal artery blood were the same), and a trocar was inserted into the left renal vein. RBF was measured using Doppler flow probes (PS \& PR Series, Transonic Systems). These data were collected and stored using the Data Acquisition System at 1-minute intervals throughout the experiment.

\section{Systemic and renal metabolism}

Blood samples were collected using PICCO and the Swan-Ganz catheter to analyze oxyhemoglobin saturation $\left(\mathrm{SO}_{2}\right)$, oxygen pressure $\left(\mathrm{PO}_{2}\right)$, partial pressure of carbon dioxide $\left(\mathrm{PCO}_{2}\right), \mathrm{pH}$, base excess $(\mathrm{BE})$, electrolytes, and renal function at 1-hour intervals. Systemic and renal oxygen metabolism indexes, such as oxygen delivery $\left(\mathrm{DO}_{2}\right), \mathrm{VO} 2$, and $\mathrm{O}_{2} \mathrm{ER}$, were measured using a blood gas analyzer (Radiometer ABL 520, Denmark). A urinary catheter was inserted into the bladder to monitor the urine output. The filtration fraction $(\mathrm{FF})$ was calculated as the creatinine clearance rate $(\mathrm{CCr}) / \mathrm{RBF}^{*}(1-\mathrm{Hct})$. Finally, the level of lactate in the arterial blood was measured as a sensitive biomarker of septic AKI.

\section{Hematoxylin-eosin staining for renal pathophysiology}

Renal tissues were immediately harvested and fixed with $4 \%$ paraformaldehyde, embedded in paraffin, and sectioned at a 4- $\mu \mathrm{m}$ thickness 2, 4, or $6 \mathrm{~h}$ after LPS infusion in the experimental group and $6 \mathrm{~h}$ after saline infusion in the control group. The sections were subsequently analyzed by hematoxylin-eosin (HE) staining [15] and mounted using neutral balsam. The renal cortex, corticomedullary zone, medulla layer, and inner medulla were primarily observed using Olympus IX51optical microscopy. Semiquantitative scores for tubular cell injury and acute tubular cell necrosis (ATN score) were used to evaluate renal damage by histology. The percentage of tubules that represented cellular necrosis, loss of brush border, vacuolization, cast formation, and tubule dilation was scored as follows: 0 (none) (1-10\%), 2 (11-25\%), 3 (26-45\%), $4(46-75 \%)$, and 5 (>76\%).

\section{TUNEL for apoptosis}

In situ renal cell apoptosis was detected by the TdT-mediated dUTP nick-end labeling (TUNEL) assay, in accordance with the detection kit protocols. The renal tissues were embedded in paraffin, fixed with paraformaldehyde, and cut at a $5-\mu \mathrm{m}$ thickness. For preciseness, the observers were blinded to the groups. The slices were dewaxed at $60^{\circ} \mathrm{C}$ overnight, washed with dimethylbenzene, and subsequently hydrated using $100 \%, 95 \%, 90 \%, 80 \%$, and $70 \%$ alcohol. After hydration, the sections were digested with protein $\mathrm{K}$ (Protein K $20 \mu \mathrm{g} / \mathrm{ml}$ in $0.1 \mathrm{~mol} / \mathrm{l}$ Tris-HCL, pH7.4) at $21-37^{\circ} \mathrm{C}$ for $15 \mathrm{~min}$, inactivated by $2 \%$ hydrogen 


\section{Kidney Blood Pressure Research}

Kidney Blood Press Res 2014;39:240-251

\begin{tabular}{l|l}
\hline DOI: $10.1159 / 000355801$ & (C) 2014 S. Karger AG, Basel
\end{tabular}

Published onIIne: August 06, 2014

www.karger.com/kbr

Yang/Wang/Liu/Liu: Energy and Oxygen Metabolism During Septic AKI

peroxide for $5 \mathrm{~min}$ at room temperature, washed with phosphate-buffered saline (PBS) twice, and labeled with TUNEL reaction mixture for $60 \mathrm{~min}$ at $37^{\circ} \mathrm{C}$ in the dark. Apoptosis was assessed using a computerassisted Olympus IX51 fluorescence microscope, and the number of TUNEL-positive cells was calculated by observers who were blinded to each group. The cells in the renal cortex, corticomedullary zone, medulla layer, and inner medulla were primarily counted in 3 randomly selected fields.

HPLC to assess energy metabolism

High-performance liquid chromatography (HPLC) $[16,17]$ was conducted to measure the concentrations of energy substances, including ATP, ADP, $\mathrm{NAD}^{+}$, and $\mathrm{PCr}$, in different portions of the kidney. Numerous preliminary tests were performed to avoid degeneration of nucleotides. Renal tissues from different groups were preserved in liquid nitrogen within a few seconds after sampling. The frozen renal tissue (200 mg) was mixed with $0.42 \mathrm{M}$ perchloric acid (cold solution), grinded for $10 \mathrm{~min}$, and centrifuged $\left(4^{\circ} \mathrm{C}\right)$ at $6000 \mathrm{~g}$ for $10 \mathrm{~min}$. The supernatant $(1 \mathrm{ml})$ was neutralized with $0.5 \mathrm{~mol} / \mathrm{l} \mathrm{KOH}$ until the $\mathrm{pH}$ was 7.0 , and the mixture was subsequently replenished to $2 \mathrm{ml}$. After standing for $10 \mathrm{~min}$, the mixture was centrifuged $\left(4^{\circ} \mathrm{C}\right)$ at $6000 \mathrm{~g}$ for $10 \mathrm{~min}$, and the supernatant was filtered using a $0.45-\mu \mathrm{m}$ sieve to eliminate the impurities. Finally, $20 \mu \mathrm{l}$ of filtrate of each sample was injected directly into the reverse-phase HPLC system (Waters Alliance, USA) with a column (Waters Nova-Pak C18) temperature of $20-25^{\circ} \mathrm{C}$. The mobile phase was composed of $220 \mathrm{mmol} / \mathrm{l} \mathrm{KH}_{2} \mathrm{PO}_{4} / \mathrm{K}_{2} \mathrm{HPO}_{4}$ buffer ( $\mathrm{pH} \mathrm{7.0),} 3 \mathrm{mmol} / \mathrm{l}$ tetrabutylammonium hydroxide, and 5\% carbinol; the flow rate was $0.9 \mathrm{ml} / \mathrm{min}$. The absorbance of ATP, ADP, and NAD ${ }^{+}$was measured at $254 \mathrm{~nm}$ and that of PCr was measured at $210 \mathrm{~nm}$. The final concentration of energy substances from each sample was calculated according to the standard curve obtained from standard samples.

\section{Statistical analysis}

All of the data were analyzed using the SPSS 13.0 statistical analysis package. An intergroup comparison of measurement data was performed using an independent-samples t-test, and a nonparametric test was used if equal variance was not assumed. The results are presented as the mean and standard deviation (mean \pm SD) values. $\mathrm{P}<0.05$ was considered to be statistically significant, and $\mathrm{P}<0.01$ was considered to indicate remarkable significance.

\section{Results}

\section{Systemic and renal hemodynamics}

Systemic hemodynamic indexes showed a non-significant difference at baseline $(1 \mathrm{~h})$ between groups ( $P>0.05$ ) (Fig. 1A-I). After LPS infusion, the MAP (Fig. 1B) decreased (from $147.0 \pm 10.7 \mathrm{mmHg}$ at $0 \mathrm{~h}$ to $90.0 \pm 17.3 \mathrm{mmHg}$ at $1 \mathrm{~h} ; \mathrm{P}=0.0102$ ) compared with baseline levels and the control group, and it only showed a non-significant increase after saline administration, which successfully maintained the CVP (Fig. 1C) and PAWP (Fig. 1E) at baseline levels; a similar decrease was also observed in SVR (Fig. 1D) from 1 to $5 \mathrm{~h}$ (from $3.62 \pm 1.02 \mathrm{l} / \mathrm{min}$ at $0 \mathrm{~h}$ to $3.08 \pm 0.98 \mathrm{l} / \mathrm{min}$ at $1 \mathrm{~h} ; \mathrm{P}=0.0014$ ). Additionally, EVLW (Fig. 1G) only showed a significant increase at $6 \mathrm{~h}(\mathrm{P}=0.014)$, whereas non-significant differences were observed in other systemic hemodynamic indexes, including CO (Fig. 1A) and GEDV (Fig. 1F). For renal hemodynamics, RBF (Fig. 1H) and renal vascular resistance (RVR) (Fig. 1I) were measured. After LPS infusion, RBF showed a non-significant increase compared with baseline levels and the control group $(\mathrm{P}=0.72)$, whereas RVR decreased prominently from 1 to $3 \mathrm{~h}(\mathrm{P}=0.028)$.

\section{Systemic and renal oxygen metabolism}

Systemic oxygen metabolism, including $\mathrm{DO}_{2}$ (Fig. 2A), $\mathrm{VO}_{2}$ (Fig. 2B), and $\mathrm{O}_{2} \mathrm{ER}$ (Fig. 2C), exhibited non-significant changes after LPS infusion compared with the control group $(\mathrm{P}>0.05)$. Renal $\mathrm{VO}_{2}(4.87 \pm 1.58 \mathrm{ml} / \mathrm{min}$ at $4 \mathrm{~h}$ in the control group vs. $2.47 \pm 0.95 \mathrm{ml} / \mathrm{min}$ at $4 \mathrm{~h}$ in the LPS groups; $\mathrm{P}=0.0026)$ (Fig. $2 \mathrm{E}$ ) and $\mathrm{O}_{2} \mathrm{ER}(17.29 \pm 2.36 \%$ at $2 \mathrm{~h}$ in the control group vs. $8.02 \pm 1.35 \mathrm{ml} / \mathrm{min}$ at $2 \mathrm{~h}$ in the LPS groups; $\mathrm{P}=0.0012$ ) (Fig. $2 \mathrm{~F}$ ) decreased significantly, whereas renal $\mathrm{DO}_{2}$ (Fig. 2D) showed non-significant change. 


\section{Kidney \\ Blood Pressure Research}

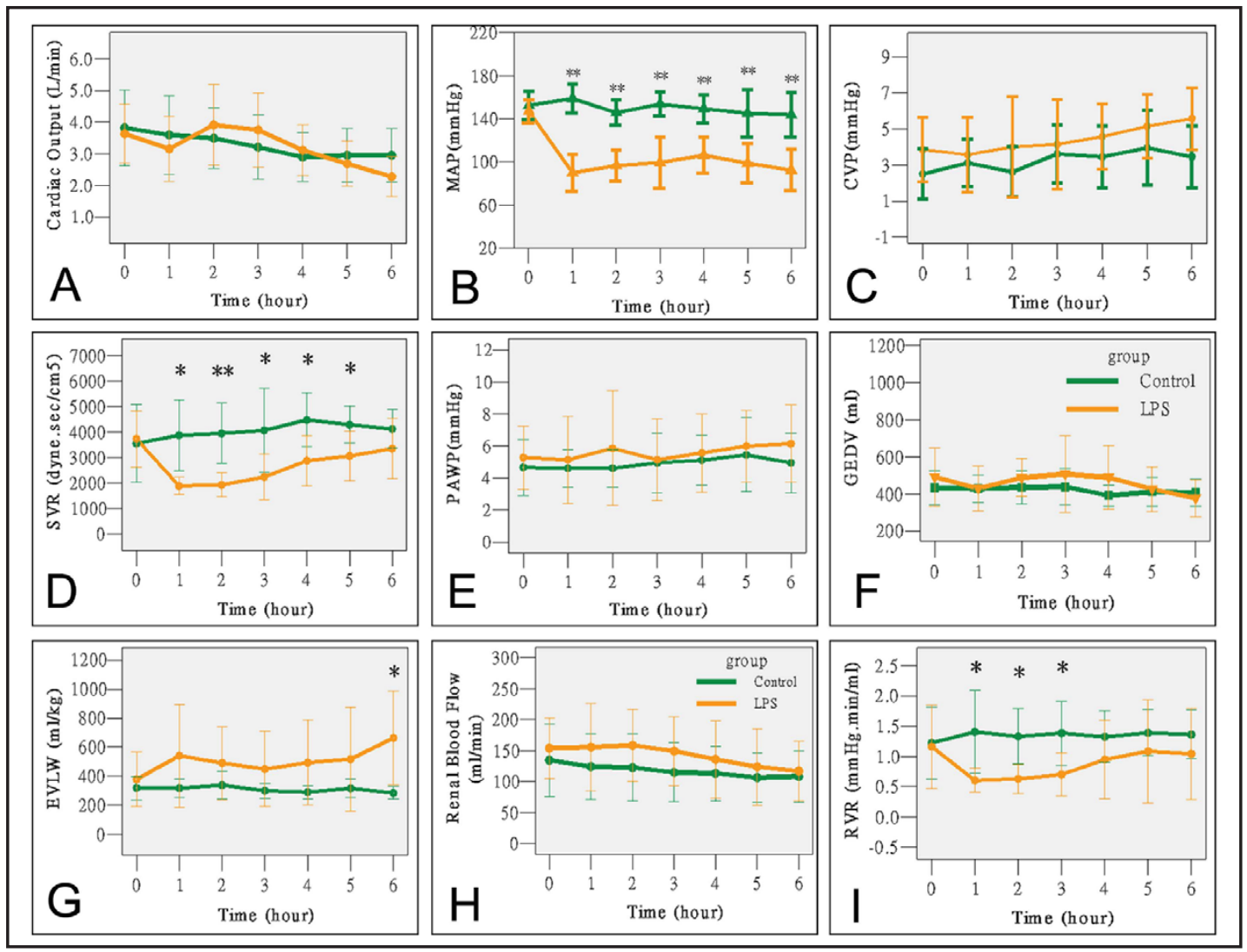

Fig. 1. Systemic and renal hemodynamics. LSP infusion (yellow) induced significant decreases in MAP, SVR, and RVR compared with the control group (green), together with an increase of EVLW, whereas CO, GEDV, and RBF remained almost unchanged. Saline infusion successfully maintained CVP and PAWP at baseline levels. *Significant difference in the LPS groups compared with the control group $(\mathrm{P}<0.05)$; ** prominent significant difference $(\mathrm{P}<0.01)$. KC, cortex of the kidney; KI, boundary of the cortex and medulla; KM, medulla of the kidney.

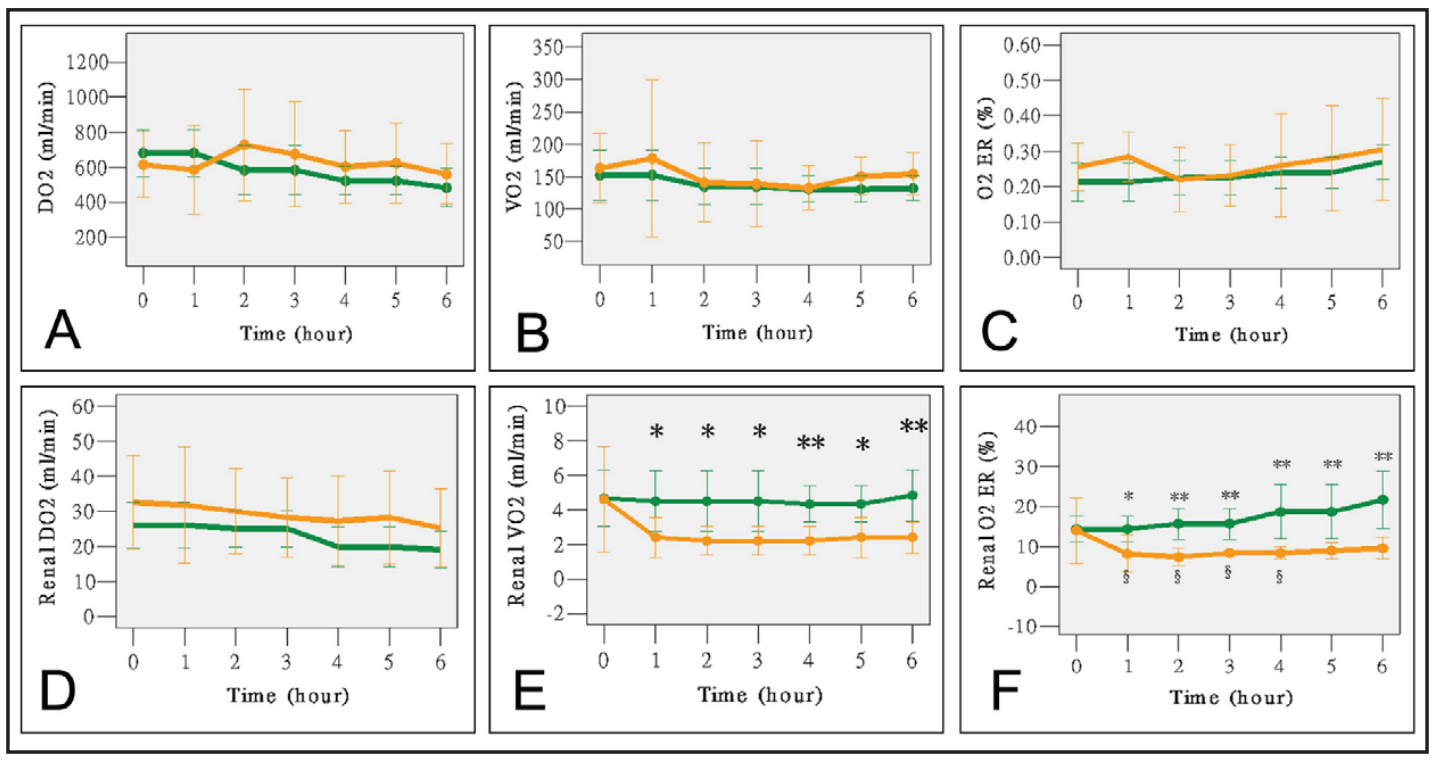

Fig. 2. Systemic and renal oxygen metabolism. LSP infusion (yellow) induced significant decreases in renal $\mathrm{VO}_{2}$ and renal $\mathrm{O}_{2} \mathrm{ER}$ compared with the control group (green), whereas systemic $\mathrm{DO}_{2}, \mathrm{VO}_{2}, \mathrm{O}_{2} \mathrm{ER}$, and renal 


\section{Kidney Blood Pressure Research}

$\mathrm{DO}_{2}$ remained nearly unchanged. *Significant difference in the LPS groups compared with the control group $(\mathrm{P}<0.05)$; ** prominent significant difference $(\mathrm{P}<0.01)$. KC, cortex of the kidney; KI, boundary of the cortex and medulla; KM, medulla of the kidney.
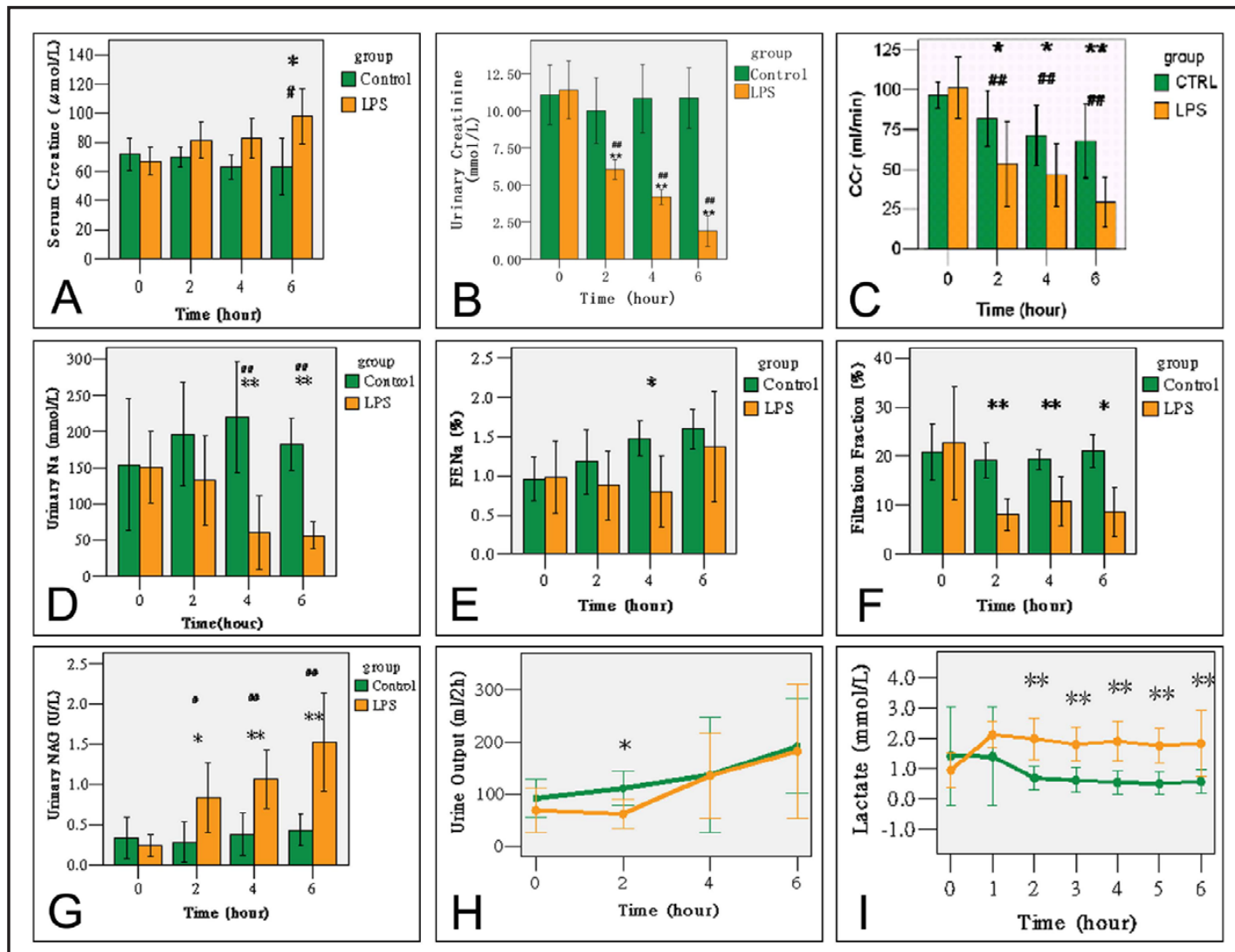

Fig. 3. Renal function and lactate. LPS infusion (yellow) induced significant decreases in UCr, CCr, urinary $\mathrm{Na}, \mathrm{FENa}$, filtration fraction, and urine output, together with evident increases in SCr compared with the control group (green). Lactate, which is a biomarker of septic shock, was increased in the LPS groups. *Significant difference in the LPS groups compared with the control group $(\mathrm{P}<0.05)$; ${ }^{* *}$ prominently significant difference $(\mathrm{P}<0.01)$; \#significant difference compared with the LPS 0 -h group $(\mathrm{P}<0.05)$; \#\#prominent significant difference $(\mathrm{P}<0.01)$. KC, cortex of the kidney; KI, boundary of the cortex and medulla; KM, medulla of the kidney.

\section{Renal function and septic shock index}

The serum creatinine (SCr) (Fig. 3A) showed a slow increase from $67.00 \pm 9.51 \mu \mathrm{M} / \mathrm{l}$ $(0 \mathrm{~h})$ to $98.03 \pm 18.88 \mu \mathrm{M} / \mathrm{l}(6 \mathrm{~h})$ compared with the baseline levels and the control group $(\mathrm{P}=0.015)$. Moreover, CCr (Fig. 3C) prominently decreased from $101.16 \pm 19.28 \mathrm{ml} / \mathrm{min}$ (at $0 \mathrm{~h}$ ) to $29.23 \pm 15.69 \mathrm{ml} / \mathrm{min}($ at $6 \mathrm{~h})(\mathrm{P}=0.0023)$, whereas the osmotic pressure exhibited a significant decrease from $1081.17 \pm 189.48 \mathrm{mOsm} / \mathrm{kg} \cdot \mathrm{H}_{2} \mathrm{O}($ at $0 \mathrm{~h}$ ) to $287.50 \pm 109.94 \mathrm{mOsm} /$ $\mathrm{kg} \cdot \mathrm{H}_{2} \mathrm{O}$ (at $\left.6 \mathrm{~h}\right)(\mathrm{P}=0.00103)$. Urinary NAG (Fig. 3G) showed a significant increase in a timedependent manner after LPS infusion. Urine creatinine (UCr) (Fig. 3B) decreased compared with the baseline and control group values $(\mathrm{P}<0.05)$. Additionally, the fractional excretion of sodium (FENa) (Fig. 3E) decreased significantly at $4 \mathrm{~h}$ after LPS infusion ( $\mathrm{P}=0.015)$. Urinary output (Fig. 3H) showed a significantly lower level in the LPS 2-h group compared with that at the same time point in the control group $(\mathrm{P}<0.01)$, followed by a slow increase 


\section{Kidney \\ Blood Pressure Research}

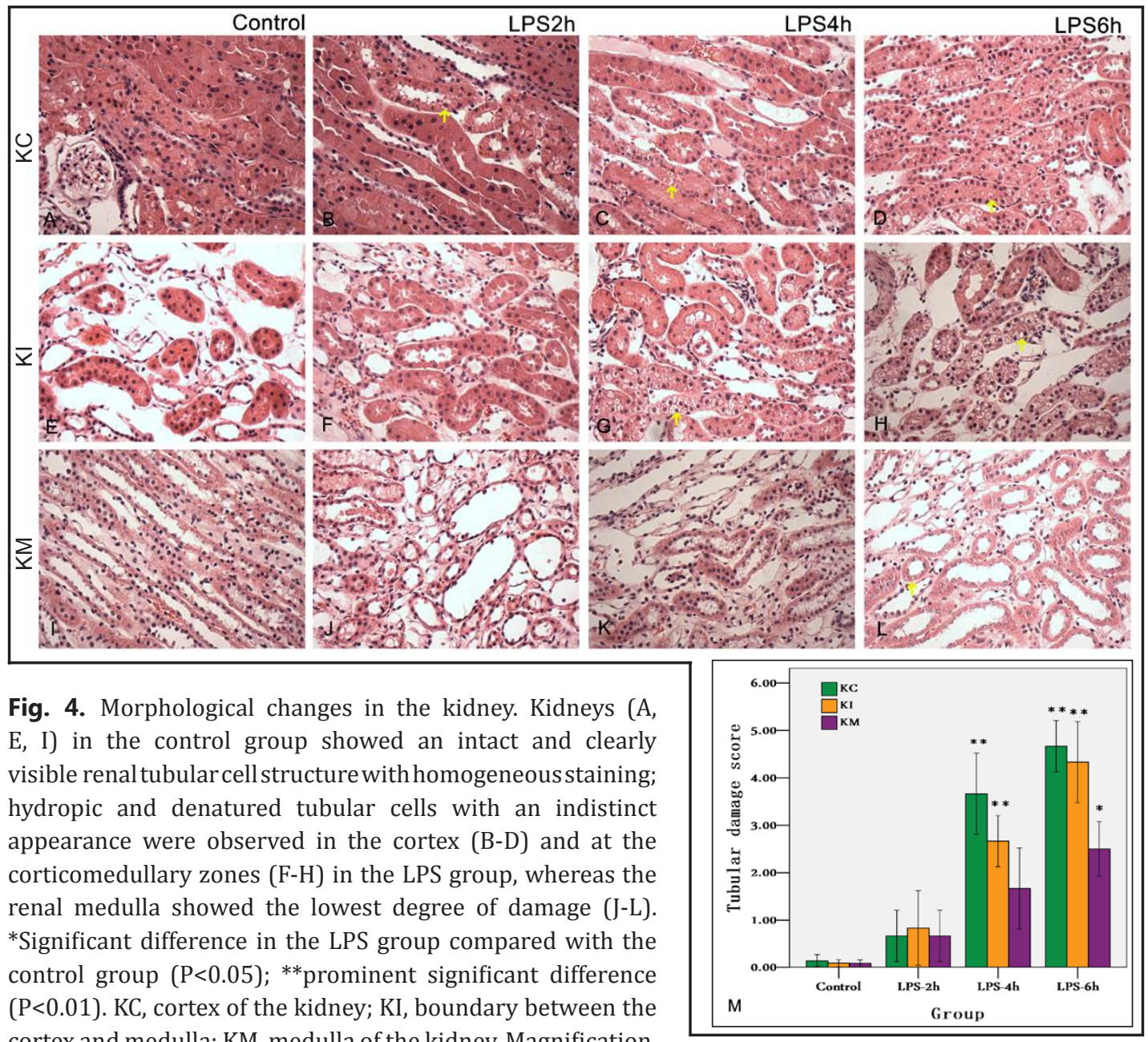

cortex and medulla; KM, medulla of the kidney. Magnification, $20 \times(A-L)$.

$2 \mathrm{~h}$ afterward. Lactate (Fig. 3I), which is a biomarker of septic shock, showed a significant increase $2 \mathrm{~h}$ after LPS infusion.

\section{Renal tubular cell injury demonstrated by HE staining}

An intact and clear renal tissue structure was observed in the control group (Fig. 4 A,E,I), whereas the LPS groups showed significant swelling, vacuolar degeneration, and cellular edema, primarily in the renal cortex (Fig. 4B-D) and corticomedullary zone (Fig. 4F$\mathrm{H}$ ), which appeared to gradually worsen in a time-dependent manner. Non-obvious necrosis was observed throughout the entire kidney. The tubular basement membrane, collecting tubule, and glomerulus in the LPS group were not different from the control group. The number of apoptotic cells only showed a significant increase $6 \mathrm{~h}$ after LPS infusion in the renal medulla (Fig. 4J-L).

\section{Tubular cell apoptosis assessed by TUNEL staining}

To explore whether LPS infusion caused cell apoptosis in the kidney, TUNEL staining was performed in each group. The results showed that $\mathrm{TUNEL}^{+}$cells were primarily observed in the proximal renal tubule in the cortex (Fig. 5A-D) and at the boundary of the cortex and medulla (Fig. 5F-H). The distribution of these cells was similar to that observed in tubular 


\section{Kidney \\ Blood Pressure \\ Research}

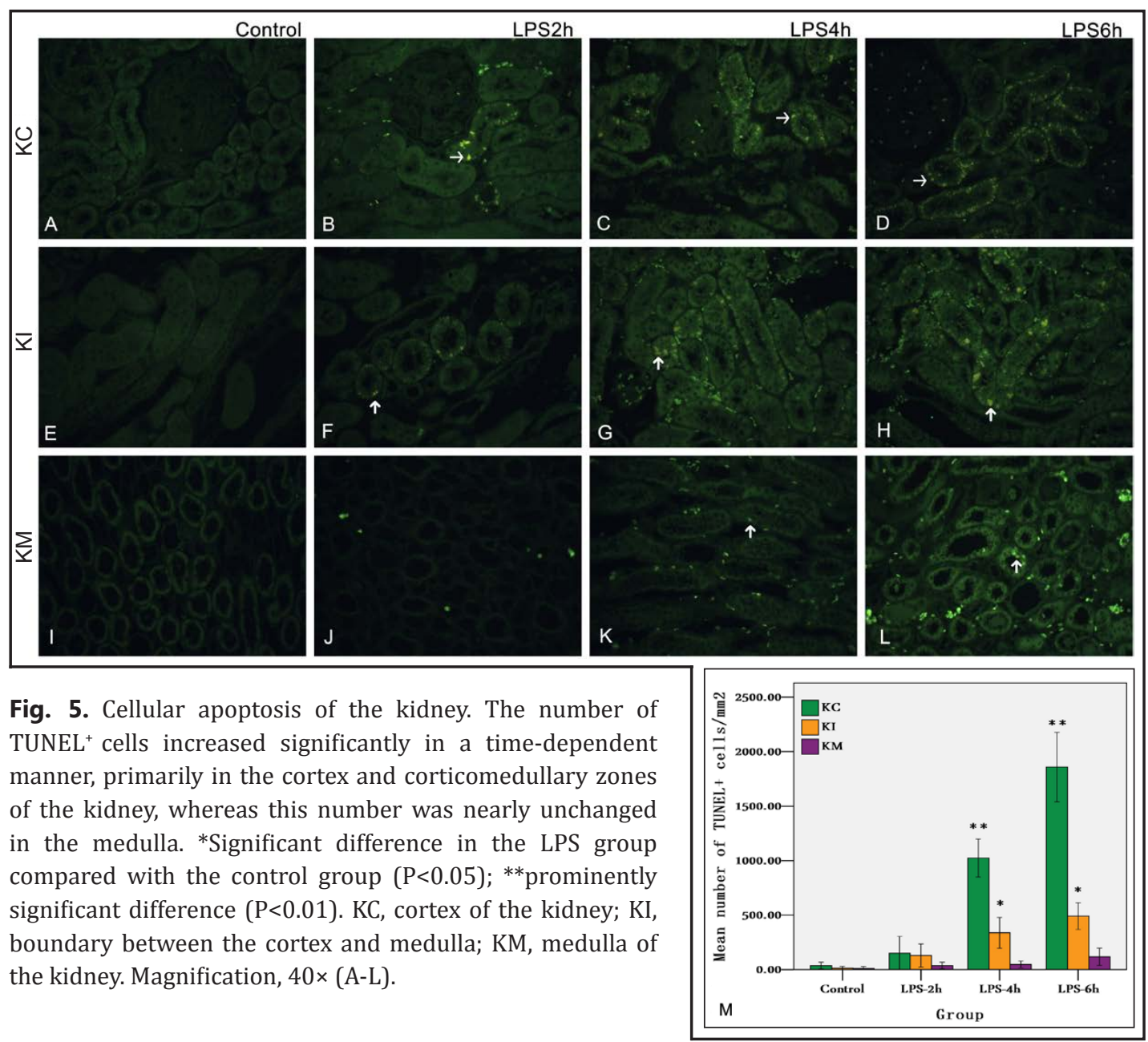

cell injury as assessed by HE staining. The number of apoptotic cells significantly increased $\left(3 \pm 1 / \mathrm{mm}^{2}\right.$ in the control group to $2351 \pm 682 / \mathrm{mm}^{2}$ in the 6 -h group, $\left.\mathrm{P}<0.01\right)$ in a timedependent manner in the LPS groups compared with the control group (Fig. 5M).

\section{Energy metabolism assessed by HPLC}

ATP, ADP, NAD ${ }^{+}$, and $\mathrm{PCr}$ in the kidney tissues were determined using HPLC. The LPS infusion resulted in significant decreases in ATP and the ATP/ADP ratio (Fig. 6A) in a time-dependent manner compared with the control group, primarily in the renal cortex. Additionally, the total $\mathrm{NAD}^{+}$pool (Fig. 6B) was reduced $2 \mathrm{~h}$ after LPS infusion; however, it was not changed thereafter, whereas the level of $\mathrm{PCr}$ (Fig. 6C) showed a significant reduction. No obvious change was detected in the renal medulla except for a slight decrease in ADP.

\section{Discussion}

Whether apoptosis or necrosis is the primary type of injury in septic AKI has been the focus of a polarized argument because of their decisively different therapeutic methods. Recent studies have reported that only slight tubular cell necrosis and significant apoptosis are the primary pathological changes associated with septic AKI $[18,19]$. However, the underlying mechanisms of tubular cell apoptosis and renal dysfunction have not been 


\section{Kidney \\ Blood Pressure Research}

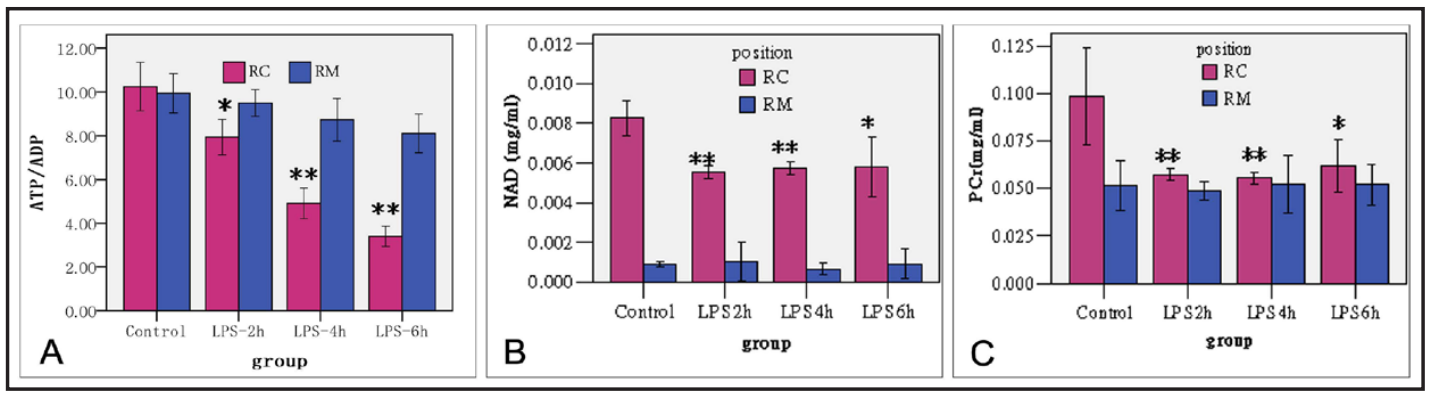

Fig. 6. Renal energy metabolism. The ATP/ADP ratio in the renal cortex showed a significant decrease in a time-dependent manner compared with its baseline level, whereas the $\mathrm{NAD}^{+}$pool and the PCr concentration in the renal cortex demonstrated significant decreases $2 \mathrm{~h}$ after LPS infusion, followed by an evident rebound $6 \mathrm{~h}$ afterward. There were non-significant changes in the ATP/ADP ratio, NAD pool, and PCr level in the renal medulla after LPS infusion compared with the baseline levels. *Significant difference in the LPS group compared with the control group $(\mathrm{P}<0.05)$; ** prominently significant difference $(\mathrm{P}<0.01)$. $\mathrm{KC}$, cortex of the kidney; KI, boundary between the cortex and medulla; KM, medulla of the kidney.

established. Moreover, the number of apoptotic tubular cells reported in the present study and other studies may not be large enough to induce severe renal injury or renal failure, thus stimulating our curiosity concerning what the actual determinant of renal dysfunction is in the early phase of septic AKI. The present study aimed to assess the hemodynamic changes in oxygen and energy metabolism in the early phase of septic AKI to explore whether energy metabolism is associated with renal dysfunction and tubular cell apoptosis.

The present study demonstrated that after LPS injection, canines presented significant renal dysfunction, indicated by significantly decreased $\mathrm{CCr}$, FF, urinary $\mathrm{Na}$, and urinary osmosis, as well as significantly increased SCr and urinary n-acetyl-beta-D-amino glycosidase enzymes (NAG), in the early phase $(2 \mathrm{~h})$. HPLC analysis revealed apparent decreases in the ATP/ADP ratio and NAD level $(2 \mathrm{~h})$, which was followed by a non-significant increase $6 \mathrm{~h}$ afterward. Additionally, HE and TUNEL staining indicated significant tubular cell injury and apoptosis $4 \mathrm{~h}$ after LPS infusion, which indicated that renal dysfunction occurred before tubular cell apoptosis. Furthermore, the number of apoptotic cells was not large enough to trigger renal dysfunction because a patient may suffer from severe kidney trauma without renal dysfunction. In summary, these factors suggest that apoptosis may not be the initiator of renal dysfunction and that functional energy impairment is more likely to be responsible for renal dysfunction.

According to the literature, the depletion of ATP can induce apoptosis, which can exacerbate cell injury and organ dysfunction [20, 21]. In energy metabolism disorders, energy-requiring biochemical processes enter into a perturbed state and subsequently cause a series of characteristic morphological changes, such as plasma membrane blebbing, which distinguishes apoptosis from necrosis (18). The present study showed a marked decrease in the ATP level and ATP/ADP ratio, primarily in the renal cortex of the kidney, before apoptosis was observed. Additionally, energy disorder and tubular cell apoptosis presented similar distributions, primarily in the renal cortex, which indicated that ATP depletion may be correlated with tubular cell apoptosis in the canine model of septic AKI. Except for ATP depletion, the present study showed a significantly decreased $\mathrm{NAD}^{+}$level, which was followed by a slow recovery. Once DNA has been damaged, $\mathrm{NAD}^{+}$can be dissociated by PARP into ADP-ribose monomers and NAD, leading to extensive consumption of NAD+. Consequently, a large amount of ATP is needed to restore the level of $\mathrm{NAD}^{+}$, and cells will finally head toward a specific programmed cell death pathway involving $\mathrm{NAD}^{+} / \mathrm{ATP}$ depletion [22-24], which suggests that $\mathrm{NAD}^{+}$depletion may be one of the reasons for the observed ATP decrease and renal dysfunction in our study. 


\section{Kidney Blood Pressure Research}

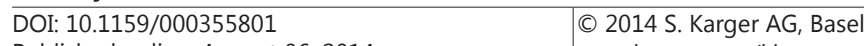

Published onlıne: August 06, 2014

www.karger.com/kb

Yang/Wang/Liu/Liu: Energy and Oxygen Metabolism During Septic AKI

Several recent studies have suggested that although RBF was not significantly reduced, a decline in renal microcirculation was detected in the renal cortex, even in the non-hypoxic area $[25,26]$, which could lead to renal hypoxia. Consistent with other studies $[2,25], \mathrm{RBF}$ and renal $\mathrm{DO}_{2}$ showed non-significant decreases in the present study, whereas renal $\mathrm{VO}_{2}$ and $\mathrm{O}_{2} \mathrm{ER}$ decreased, indicating that a renal microcirculatory disturbance or cellular failure, such as mitochondrial dysfunction, may be associated with energy disorder, cell apoptosis, and renal dysfunction in the AKI model. Recent studies have maintained that microcirculatory dysfunction in the renal cortex or renal medulla can occur despite normal or increased RBF [27]. The microcirculation is recognized to play an important role in delivering and regulating the exchange of oxygen in the surrounding tissues, which is critical for energy metabolism and cellular function [28]. This evidence indicates that microcirculatory dysfunction may be the cause of renal $\mathrm{VO}_{2}$ and $\mathrm{O}_{2} \mathrm{ER}$ decreases and the subsequent energy metabolism disorder. However, additional studies are warranted to explain why $\mathrm{VO}_{2}$ is stabilized thereafter. Is there any correlation between energy metabolism and mitochondria dysfunction? Other studies have indicated that PARP can lead to $\mathrm{NAD}^{+}$depletion and mitochondrial release of apoptosisinducing factors, which are key mediators of cell death [29]. A recent study demonstrated that NO and ROS triggered PARP-independent cell death and mitochondrial dysfunction; however, PARP inhibition did not modify the loss of mitochondrial function [30]. Another study demonstrated that energy repletion with NAD or a NAD/pyruvate mixture inhibited mitochondrial swelling and microtubule depolymerization [31]. These results suggest that many studies support a close relationship between NAD loss and mitochondrial dysfunction $[29,32]$, which may also be the cause of decreased renal $\mathrm{VO}_{2}$. However, the evidence from the present study was insufficient to reveal mitochondrial failure and the causal relationship between $\mathrm{NAD}^{+}$depletion and mitochondrial dysfunction; thus, additional studies are needed.

In the present study, energy metabolism disorder and tubular cell injury were primarily observed in the renal cortex, whereas only non-significant damage was detected in the medulla. The reason for these observations was not clear, although they may be related to differences between species, blood flow, and experimental conditions. An earlier study reported a similar distribution and showed that the basal interstitial concentration of adenosine in the renal cortex was higher than that in the medulla [33]. Additional studies must be conducted to determine whether this finding can be duplicated and confirmed in other animals and to validate the key mechanism.

\section{Conclusion}

The present study indicated that tubular cell apoptosis may not be the cause of renal dysfunction during septic AKI and that ATP depletion, which may originate from $\mathrm{NAD}^{+}$ depletion caused by DNA damage, is more likely to be the cause of renal dysfunction or even tubular cell death. However, because of the very short time period of the septic AKI study, we recommend that longer and more experimental and clinical studies be performed. Moreover, many studies have shown that $\mathrm{NAD}^{+}$administration can alleviate oxidative cell death, trauma, and X-ray-induced tissue injury. Additional experiments will explore whether $\mathrm{NAD}^{+}$ metabolism disorder plays a key role in renal dysfunction and whether $\mathrm{NAD}^{+}$administration can become a therapeutic method for preventing and treating septic AKI.

\section{Disclosure Statement}

Rong-li Yang and the other co-authors declare that they have no conflicts of interest. 


\section{Kidney \\ Blood Pressure Research}

Yang/Wang/Liu/Liu: Energy and Oxygen Metabolism During Septic AKI

\section{Acknowledgments}

We thank Peking Union Medical College Hospital for assisting us with the instruments and equipment used to conduct our study. We acknowledge Daiwei Liu and all the people for their helpful guidance and constructive advice. We especially thank Sibo Liu and Xiaoting Wang for performing data collection and analysis.

\section{References}

1 Romanovsky A, Morgan C, Bagshaw SM: Pathophysiology and management of septic acute kidney injury. Pediatr Nephrol 2014;29:1-12.

-2 Chvojka J, Sykora R, Krouzecky A, Radej J, Varnerova V, Karvunidis T, Hes O, Novak I, Radermacher P, Matejovic M: Renal haemodynamic, microcirculatory, metabolic and histopathological responses to peritonitis-induced septic shock in pigs. Crit Care 2008;12:R164.

3 May CN, Calzavacca P, Ishikawa K, Langenberg C, Wan L, Ramchandra R, Bellomo R: Novel targets for sepsis-induced kidney injury: the glomerular arterioles and the sympathetic nervous system. Exp Physiol 2012;97:1168-1177.

-4 Jacobs R, Honore PM, Joannes-Boyau O, Boer W, De Regt J, De Waele E, Collin V, Spapen HD: Septic acute kidney injury: the culprit is inflammatory apoptosis rather than ischemic necrosis. Blood Purif 2011;32:262-265.

5 Johannes T, Mik EG, Klingel K, Dieterich HJ, Unertl KE, Ince C: Low-dose dexamethasone-supplemented fluid resuscitation reverses endotoxin-induced acute renal failure and prevents cortical microvascular hypoxia. Shock 2009;31:521-528.

-6 Holthoff JH, Wang Z, Patil NK, Gokden N, Mayeux PR: Rolipram improves renal perfusion and function during sepsis in the mouse. J Pharmacol Exp Ther 2013;347:357-364.

7 Dirkes S: Sepsis and inflammation: impact on acute kidney injury. Nephrol Nurs J 2013;40:125-132; quiz 133.

8 Lee SY, Lee YS, Choi HM, Ko YS, Lee HY, Jo SK, Cho WY, Kim HK: Distinct pathophysiologic mechanisms of septic acute kidney injury: role of immune suppression and renal tubular cell apoptosis in murine model of septic acute kidney injury. Crit Care Med 2012;40:2997-3006.

-9 Bellomo R, Bagshaw S, Langenberg C, Ronco C: Pre-renal azotemia: a flawed paradigm in critically ill septic patients? Contrib Nephrol 2007;156:1-9.

10 Lieberthal W, Menza SA, Levine JS: Graded ATP depletion can cause necrosis or apoptosis of cultured mouse proximal tubular cells. Am J Physiol 1998;274:F315-F327.

11 Chevalier RL, Forbes MS: Generation and evolution of atubular glomeruli in the progression of renal disorders. J Am Soc Nephrol 2008;19:197-206.

12 Scorrano L: Keeping mitochondria in shape: a matter of life and death. Eur J Clin Invest 2013;43:886-893.

13 Birk AV, Liu S, Soong Y, Mills W, Singh P, Warren JD, Seshan SV, Pardee JD, Szeto HH: The mitochondrialtargeted compound SS-31 re-energizes ischemic mitochondria by interacting with cardiolipin. J Am Soc Nephrol 2013;24:1250-1261.

14 Guzman JA, Rosado AE, Kruse JA: Vasopressin vs norepinephrine in endotoxic shock: systemic, renal, and splanchnic hemodynamic and oxygen transport effects. J Appl Physiol (1985) 2003;95:803-809.

15 Martinez Lalis R, Esain ML, Kokubu GA, Willis J, Chaves C, Grana DR: Rat subcutaneous tissue response to modified Portland cement, a new mineral trioxide aggregate. Braz Dent J 2009;20:112-117.

16 Christen M, Christen B, Folcher M, Schauerte A, Jenal U: Identification and characterization of a cyclic diGMP-specific phosphodiesterase and its allosteric control by GTP. J Biol Chem 2005;280:30829-30837.

17 Botker HE, Kimose HH, Helligso P, Nielsen TT: Analytical evaluation of high energy phosphate determination by high performance liquid chromatography in myocardial tissue. J Mol Cell Cardiol 1994;26:41-48.

18 Choi HM, Jo SK, Kim SH, Lee JW, Cho E, Hyun YY, Cha JJ, Kang YS, Cha DR, Cho WY, Kim HK: Glucocorticoids attenuate septic acute kidney injury. Biochem Biophys Res Commun 2013;435:678-684. 


\section{Kidney \\ Blood Pressure Research}

19 Kockara A, Kayatas M: Renal cell apoptosis and new treatment options in sepsis-induced acute kidney injury. Ren Fail 2013;35:291-294.

-20 Wang Z, Havasi A, Gall J, Bonegio R, Li Z, Mao H, Schwartz JH, Borkan SC: GSK3beta promotes apoptosis after renal ischemic injury. J Am Soc Nephrol 2010;21:284-294.

21 Kim M, Park SW, Kim M, Chen SW, Gerthoffer WT, D'Agati VD, Lee HT: Selective renal overexpression of human heat shock protein 27 reduces renal ischemia-reperfusion injury in mice. Am J Physiol Renal Physiol 2010;299:F347-F358.

22 Musumeci G, Castrogiovanni P, Loreto C, Castorina S, Pichler K, Weinberg AM: Post-traumatic caspase-3 expression in the adjacent areas of growth plate injury site: a morphological study. Int J Mol Sci 2013;14:15767-15784.

-23 Morotomi-Yano K, Akiyama H, Yano K: Nanosecond pulsed electric fields induce poly(ADP-ribose) formation and non-apoptotic cell death in HeLa S3 cells. Biochem Biophys Res Commun 2013;438:557562 . Berger NA: Poly(ADP-ribose) in the cellular response to DNA damage. Radiat Res 1985;101:4-15. Johannes T, Mik EG, Ince C: Nonresuscitated endotoxemia induces microcirculatory hypoxic areas in the renal cortex in the rat. Shock 2009;31:97-103.

-26 Wu L, Tiwari MM, Messer KJ, Holthoff JH, Gokden N, Brock RW, Mayeux PR: Peritubular capillary dysfunction and renal tubular epithelial cell stress following lipopolysaccharide administration in mice. Am J Physiol Renal Physiol 2007;292:F261-F268.

27 Bougle A, Duranteau J: Pathophysiology of sepsis-induced acute kidney injury: the role of global renal blood flow and renal vascular resistance. Contrib Nephrol 2011;174:89-97.

28 Ghonaim NW, Fraser GM, Ellis CG, Yang J, Goldman D: Modeling steady state S02-dependent changes in capillary ATP concentration using novel 02 micro-delivery methods. Front Physiol 2013;4:260.

29 Alano CC, Garnier P, Ying W, Higashi Y, Kauppinen TM, Swanson RA: NAD+ depletion is necessary and sufficient for poly(ADP-ribose) polymerase-1-mediated neuronal death. J Neurosci 2010;30:2967-2978.

30 Broniowska KA, Diers AR, Corbett JA, Hogg N: Effect of nitric oxide on naphthoquinone toxicity in endothelial cells: role of bioenergetic dysfunction and poly(ADP-ribose) polymerase activation. Biochemistry 2013;52:4364-4372.

-31 Park JY, Jang SY, Shin YK, Koh H, Suh DJ, Shinji T, Araki T, Park HT: Mitochondrial swelling and microtubule depolymerization are associated with energy depletion in axon degeneration. Neuroscience 2013;238:258269.

-32 Kristian T, Balan I, Schuh R, Onken M: Mitochondrial dysfunction and nicotinamide dinucleotide catabolism as mechanisms of cell death and promising targets for neuroprotection. J Neurosci Res 2011;89:19461955.

33 Yao K, Heyne N, Erley CM, Risler T, Osswald H: The selective adenosine A1 receptor antagonist KW-3902 prevents radiocontrast media-induced nephropathy in rats with chronic nitric oxide deficiency. Eur J Pharmacol 2001;414:99-104. 